\title{
Large ungulate habitat preference in Chobe National Park, Botswana
}

\author{
UYAPO J. OMPHILE AND JEFF POWELL
}

Authors are Lecturer, Botswana College of Agriculture, Gaborone; and Professor of Rangeland Livestock-Wildlife Relations, Wyoming Agricultural Experiment Station, Laramie, Wyo, USA.

\begin{abstract}
Both large ungulates and wildlife tourists tend to concentrate along the Chobe River in Chobe National Park, Botswana, during the dry season causing concern for wildlife habitat and the recreational experience for wildlife viewers. Therefore, ground reconnaissance inventory data of 5 most common large ungulates were collected during the early morning and late afternoon hours along tourist routes in 5 different habitat types every second month for a period of $\mathbf{2 4}$ months in Chobe National Park to determine their relative, seasonal habitat preference and availability for viewing by vehicular tourists. A total of 909 herds: greater kudu (Tragelaphus strepsiceros), 285; impala (Aepyceros melampus), 209; elephant (Loxodonta africana), 200; giraffe (Giraffa camelopardalis), 138; and buffalo (Syncerus caffra), 77 were observed during the 760 observation periods. The average frequency of observation of a herd of 1 or more of these 5 ungulates per habitat type was alkali flats, 3.42; floodplain grassland, 2.67; shrub savanna, 2.29; tree savanna, 1.04; and woodland, 0.30. This order of frequency of observation is highly correlated with nearness to the Chobe River, the major water source during the dry season. Elephant and giraffe were more wide-ranging than buffalo, impala, and kudu. During the dry season, all animals were seen more often on the floodplain grassland in the afternoon than in the morning. Giraffe were never seen in any habitat type in December, and impala were never seen in the woodland in any month. Our data confirm that tour operators interested primarily in providing their guests with a view of the greatest numbers of animals in a limited period of time are justified in congregating along the Chobe River during the dry season. However, as in most public wildlife reserves, Chobe National Park management is faced with the decision of how best to optimize the biological needs of Park animals and their habitat with the economic and recreational desires of Park users.
\end{abstract}

Key Words: Southern Africa, recreationists, buffalo, elephant, giraffe, impala, kudu

Chobe National Park is one of Botswana's major tourist attractions, primarily because of the variety of large animals present. In monetary terms, McNeeley (1988) estimated that a lion in Amboseli National Park, Kenya is worth $\$ 27,000$ per year in tourist attraction, and each elephant herd is worth $\$ 610,000$ per year. In 1999, about 89,540 tourists visited Chobe National Park

Research was funded in part by the Kellogg Foundation.

Manuscript accepted 24 Sept. 01

\author{
Resumen
}

Durante la estación seca los grandes ungulados y los turistas de la fauna silvestre tienden a concentrarse a lo largo del río Chobe en el Parque Nacional Chobe de Botswana, causando preocupación por el hábitat y la experiencia recreacional de los observadores de fauna silvestre. Por lo tanto, cada dos meses durante un periodo de 24 meses, se colectaron en el Parque Nacional Chobe datos de un inventario de reconocimiento terrestre de los 5 grandes ungulados mas comunes. La colecta de datos se realizo temprano en la mañana y en la tarde a lo largo de rutas de turistas en 5 diferentes tipos de hábitat para determinar la preferencia estacional relativa de hábitat y la disponibilidad para ser visto por turistas en vehículos. Un total de 909 manadas, 285 de Gran kudu (Tragelaphus strepsiceros), 209 de Impala (Aepyceros melampus), 200 de elefante (Loxodonta africana), 138 de jirafa; (Giraffa camelopardalis), 77 de búfalo (Syncerus caffra), se observaron durante $\mathbf{7 6 0}$ periodos de observación. La frecuencia promedio de observación de una manada de uno o más de estos 5 ungulados por tipo de hábitat fue de $\mathbf{3 . 4 2}$ para las llanuras alcalinas, 2.67 para los pastizales inundables, 2.29 para la savana con arbustos, 1.04 para la savana con árboles y 0.30 para los bosques. Este orden de frecuencia de observación esta altamente correlacionada con la cercanía del río Chobe, la mayor fuente de agua durante la época seca. El elefante y la girafa tuvieron un rango mas amplio de dispersión que el búfalo, el impala y el kudu. Durante la época seca todos los animales fueron vistos mas a menudo en los pastizales inundables durante la tarde que durante la mañana. Las jirafas nunca fueron vistas en diciembre en ninguno de los hábitats y los impalas no fueron vistos en el bosque en ninguno de los meses. Nuestros datos confirman que los operadores de recorridos interesados principalmente en proveer a sus invitados una vista con el mayor número de animales en un periodo de tiempo limitado son justificados en congregase a lo largo del río Chobe durante la época seca. Sin embargo, como en la mayoría de las reservas públicas de fauna silvestre, el manejo del Parque Nacional Chobe, se encara con la decisión de como optimizar mejor las necesidades biológicas de los animales del parque y su hábitat con los deseos económicos y recreacionales de los usuarios del parque.

for 108,700 tourist-days or 1.21 days/tourist (pers. commun., Botswana Dep. National Parks and Wildlife). Tourists included $27 \%$ who drove their own vehicles and $73 \%$ guided by commercial tour operators. Most $(56 \%)$ of the private visitors were from Southern Africa, whereas guided visitors were primarily $(81.3 \%)$ from countries outside Africa. Private visitors provided $40 \%$ of 
the total 21,833 vehicle-days with an average of 3.5 people per vehicle; tour operators provided $60 \%$ of the vehicle-days with an average of 6.0 people per vehicle.

The majority of visitors tour Chobe National Park during the dry, winter season (pers. commun., Botswana Dept. National Parks and Wildlife) because the temperature is cooler, the risk of malaria is lower, and the loss of leaves from deciduous trees and shrubs during the dry season enhances wildlife viewing (pers. observ.). In addition, nearly all large animals tend to concentrate near the Chobe River along the northern edge of the Park at this time because other water sources are limited.

The concentration of animals along the northern edge of the Park during the dry season attracts wildlife-viewing tourists, thus apparently leaving much of the Park under-utilized by both animals and tourists at this time. The Botswana Department of National Parks and Wildlife is concerned about the "over-crowding" of animals and tourists along the northern edge of the Park, and therefore, the objective of this study was to document the numbers of herds of 5 common ungulate species in different habitat types and in different seasons as "seen by vehicular tourists". The 5 species included 2 browsers, giraffe (Giraffa camelopardalis) and greater kudu (Tragelaphus strepsiceros), 2 mixed feeders, elephant (Loxodonta Africana) and impala (Aepyceros melampus), and 1 grazer, buffalo (Syncerus caffra) to reflect the range of large ungulate herbivory in the study area.

\section{Materials and Methods}

\section{Study Area}

Location and general description.-The study area is located in the northern part of Chobe National Park, Botswana. The Park covers an area of $11,000 \mathrm{~km}^{2}$ and lies between longitude $24^{\circ}$ and $25^{\circ} \mathrm{E}$ and latitude $18^{\circ}$ and $19^{\circ} \mathrm{S}$ (Child 1968). It is partially drained by the Chobe River which forms the boundary between northeastern Botswana and eastern Carprivi Strip of Namibia. The river meanders through an extensive floodplain which stretches east almost unbroken to the Zambezi River in Zambia and abruptly gives way to a sand ridge composed of a basaltic core overlain by the Kgalagadi sand to the south (Child and Von Richter 1968). The interior of the Park is drained by the ephemeral Savuti and Ngwezumba rivers and numerous intermittent streams.

Climate.-Rainfall is seasonal, falling mainly between November and April. Precipitation at Kasane averages $690 \mathrm{~mm}$ (Child and Von Richter 1968) with a $70-80 \%$ probability of exceeding $500 \mathrm{~mm}$ in any one year (Field 1978). The remaining months of the year are dry, and the degree of dryness increases progressively from June to October. Maximum and minimum average monthly temperatures range from 36 to $19^{\circ} \mathrm{C}$, but decline to winter minima in June and July when the range is between 26 and $9 \mathrm{C}$. Temperatures reach a maximum in October when the average maximum over 24 years was $35^{\circ} \mathrm{C}$ and the minimum was $19^{\circ} \mathrm{C}$ (Child and Von Richter 1968).

Topography.-Northeastern Botswana, like the rest of the country, is relatively flat terrain characterized by low elevation ranging from 100 to $1,000 \mathrm{~m}$ (Field 1978). Within the park, however, elevations only range from 910 to $1,050 \mathrm{~m}$ (FGU undated).

Soils and vegetation.-The Park is ecologically divided into 5 zones; the Chobe floodplain grassland in the north, Mababe depression and Savuti channel and marsh in the southwest, the Pan area into which the Ngwezumba River empties, and the Kgalagadi woodland which covers most of the Park. The study site includes both Kgalagadi woodland and Chobe floodplains. Within the woodland, 2 additional areas (i.e., tree savanna and shrub savanna) were identified for the purposes of the study. These areas, together with a third habitat type, the alkali flats, were described (Selous 1881, Henry 1966) and referred to (Child 1968) as variations within a broader vegetation type. Therefore, we considered 5 areas (i.e., floodplain grassland, alkali flats, shrub savanna, tree savanna, and Kgalagadi woodland) as 5 ecologically distinct habitat types affecting ungulate behavior and ecology in this study.

The total area of study is about $575 \mathrm{~km}^{2}$ or about $5 \%$ of the total Park area. Within the study area, the habitat type composition is as follows: woodland $(55.6 \%)$, tree savanna $(23.7 \%)$, floodplain grassland $(11.1 \%)$, shrub savanna $(5.2 \%)$, and alkali flats $(4.2 \%)$.

The Chobe floodplain grasslands, an integral part of the Chobe River system, is a linear area of approximately $90 \mathrm{~km}^{2}$ bordering and including part of the river. The soils differ, but are characterized by calcic gleysols and eutric arenosols, deep to very deep, poorly to imperfectly drained, very dark sand clay to clay interspersed by riverine alluvials on dead river courses (FGU undated).

The Kgalagadi woodland is an open woodland, probably fire-induced as evi- dent from tree stumps and bark-bearing fire scars. The area tends towards a forest to the east between Kasane and Lesoma, stretches south from the crest of the savanna (sandridge) to the edge of the Kakulani plains around Ngwezumba River and from Kasane, southwest to Kachikau. The soils (FGU undated) are predominantly ferralic arenosols to eutric arenosols, deep to very deep and excessively drained. Locally, these soils are interspersed with a variety of loamy sands on alluvial deposits in the valleys.

Savanna soils are consistently sandy and lack interruptions except on rocky outcrops where larger rock boulders or loose gravel replace the sand. The habitat abruptly gives way either to the Chobe floodplains, alkali flats, or the shrub savanna to the north and west, and the Kgalagadi woodland to the south. Although logging was reported (Miller 1939), and signs of that activity are still evident, especially to the north, the industry does not appear to have significantly affected the tree population.

The shrub savanna, an extension of the tree savanna, but with an ecologically distinct characteristic resulting from excessive logging during the turn of the century (Child 1968) and excessive use of the woody vegetation by elephants, is located east of the sand ridge and alkali flats and west of the Sedudu valley. The soils are generally sandy, but stretches of harder loamy soil, especially around the few pans, are common.

The alkali flats is an open area, though some portions, especially those within the sandy soils catena, have a closed canopy of tall brush. This area, believed to be an elevated floodplain and named "Puku" flats (Selous 1881) is oblong in shape and about 9-13 km long, but rather narrow (0.5-1.2 km wide).

\section{Observational Methods}

The 5 animal species selected for study were observed in each of the 5 habitat types delineated in the study area. Reconnaissance tours (Dekker et al. 1996) were conducted during the first 3 hours of daylight and the last 3 hours before dark every other day for a minimum of 5 and a maximum of 7 different days per month during both wet and dry seasons from October 1993 through August 1995. Observational data recorded for each herbivore included habitat type, location within habitat type, and distance (m) from observer to animal.

The line transect method (Mugangu et al. 1995) was used for data recording. The 
route of each reconnaissance tour was limited by vehicular accessibility. However, all habitat types were sampled during each observation period, and the route order was randomized by and within habitat types to obtain an estimate of the preferred habitat types based on relative numbers of herds of different species of animals sighted in each habitat type. Animals seen along habitat type ecotones were not recorded, and only those sighted in a habitat type that was currently being monitored were considered valid observations.

The total number of habitat preference samples (observation means) per species was: 2 years x 6 months/year x 5 habitat types/month x 5-7 days/month $\times 2$ times /day $=760$ observation periods. The number of observations of herds of an herbivore in each habitat type was adjusted by a factor to compensate for the different distances traveled in different habitat types. The distances traveled each observation period in the different habitat types were alkali flats $(28.4 \mathrm{~km})$, floodplain grassland $(23.4 \mathrm{~km})$, shrub savanna $(21.3 \mathrm{~km})$, tree savanna $(40.7 \mathrm{~km})$, and woodland $(30.5 \mathrm{~km})$ for a total of $144 \mathrm{~km}$ or an average of $28.8 \mathrm{~km}$ per habitat type each observation period.

The recording team included a driver and 2 observers in the back of a pickup truck. Each observer recorded individually, and the 2 observations were averaged for each kind of herbivore. Due to differences in vegetation cover density, the sighting distance (Dekker et al. 1996) varied among the different vegetation types. The initial sighting distance was disregarded because of the emphasis on the "tourist viewing perspective". In other words, the objective was to determine how many herds of a species a tourist would see from a vehicle along routes of vehicular access in different habitat types in Chobe National Park. Not all species were observed in all habitat types or in all observation periods. However, if more than one herd of the same species was observed at different locations in the same habitat type during the same observation period, each herd was counted as a separate observation.

The general linear model (GLM) procedure (SAS 1985) was used for a split (time of day)- split (habitat type) - plot (month) experimental design (Steel and Torrie
1980) using years as replications to determine the level of significance among differences in habitat type preference for different times of day and months by different herbivore species. Where significant $(\mathrm{P}<0.05)$ differences were observed, Tukey's HSD was used to separate the means. All differences discussed are statistically significant at the $5 \%$ level unless otherwise indicated.

\section{Results}

\section{Weather}

Annual precipitation during the 2 wetto-dry years from October, 1993 through September, 1995 was about equal but $20 \%$ less in both years than the long-term average. The early wet season rains in the first year (PY94; 10/93-9/94) were about average, but there were only limited rains after February 1994. Early wet season precipitation in PY95 (10/94-9/95) was less than that in PY94; however, above average rainfall in February 1995 brought the cumulative total up to equal that of PY94. The net effects were to create normal plant

Table 1. Numbers (mean \pm SE) of buffalo herds observed per time period during different months, times of day, and in different habitat types in Chobe National Park, Botswana. ( $N=6 / \mathrm{month} /$ time period/habitat type). Means for habitat types for the same time or month followed by a different letter are statistically different at the $5 \%$ level of probability. Significant $(P<0.05)$ differences between means for different times within habitat type and month are indicated by '*',

\begin{tabular}{|c|c|c|c|c|c|c|c|}
\hline \multirow[b]{2}{*}{ Month } & \multirow[b]{2}{*}{ Time $^{2}$} & \multicolumn{5}{|c|}{ Habitat Type $^{1}$} & \multirow[b]{2}{*}{ HTMean $^{3}$} \\
\hline & & $\mathrm{AF}$ & $\mathrm{FG}$ & SS & TS & WL & \\
\hline \multirow[t]{3}{*}{ Year $^{4}$} & $\mathrm{AM}$ & $0.17 \mathrm{a} \pm 0.04$ & $0.2 b \pm 0.02$ & $0.11 \mathrm{ab} \pm 0.04$ & $0.18 * a \pm 0.04$ & $0.01 b \pm 00.01$ & $0.10 \pm 0.02$ \\
\hline & PM & $\underline{0.10 b \pm 0.03}$ & $\underline{0.43 * \mathrm{a} \pm 0.08}$ & $0.09 \mathrm{~b} \pm 0.04$ & $0.02 b \pm 0.01$ & $0.0 \mathrm{~b} \pm 0.0$ & $\underline{0.13 \pm 0.02}$ \\
\hline & TMean $^{5}$ & $\overline{0.13 b \pm 0.03}$ & $0.22 \mathrm{a} \pm 0.04$ & $\overline{0.10 b \pm 0.03}$ & $\overline{0.10 b \pm 0.02}$ & $0.01 \mathrm{c} \pm 0.01$ & $0.11 \pm 0.01$ \\
\hline \multirow[t]{3}{*}{ Dec. } & $\mathrm{AM}$ & $0.25 \pm 0.13$ & $0.10 \pm 0.10$ & $0.11 \pm 0.11$ & $0.12 \pm 0.08$ & $0.0 \pm 0.0$ & $0.12 \pm 0.04$ \\
\hline & PM & $\underline{0.09 \pm 0.09}$ & $\underline{0.21 \pm 0.14}$ & $\underline{0.0 \pm 0.0}$ & $\underline{0.0 \pm 0.0}$ & $\underline{0.0 \pm 0.0}$ & $\underline{0.06 \pm 0.03}$ \\
\hline & TMean & $0.17 \pm 0.08$ & $0.15 \pm 0.09$ & $0.06 \pm 0.06$ & $0.06 \pm 0.04$ & $0.0 \pm 0.0$ & $0.09 \pm 0.03$ \\
\hline \multirow[t]{3}{*}{ Feb. } & $\mathrm{AM}$ & $0.07 \pm 0.07$ & $0.0 \pm 0.0$ & $0.21 \pm 1.04$ & $0.11 \pm 0.07$ & $0.0 \pm 0.0$ & $0.08 \pm 0.04$ \\
\hline & PM & $\underline{0.16 \pm 0.11}$ & $0.0 \pm 0.0$ & $\underline{0.10 \pm 1.00}$ & $\underline{0.11 \pm 0.07}$ & $\underline{0.0 \pm 0.0}$ & $\underline{0.07 \pm 0.03}$ \\
\hline & TMean & $\overline{0.11 \pm 0.06}$ & $\overline{0.0 \pm 0.0}$ & $\overline{0.16 \pm 0.09}$ & $\overline{0.11 \pm 0.05}$ & $\overline{0.0 \pm 0.0}$ & $\overline{0.08 \pm 0.02}$ \\
\hline \multirow[t]{3}{*}{ Apr. } & $\mathrm{AM}$ & $0.23 \pm 0.12$ & $0.0 \pm 0.0$ & $0.10 \pm 0.10$ & $0.22 * \pm 0.09$ & $0.0 \pm 0.0$ & $0.11 \pm 0.04$ \\
\hline & PM & $\underline{0.16 \pm 0.11}$ & $\underline{0.28 * \pm 0.15}$ & $\underline{0.10 \pm 0.10}$ & $\underline{0.0 \pm 0.0}$ & $\underline{0.0 \pm 0.0}$ & $\underline{0.11 \pm 0.04}$ \\
\hline & TMean & $0.20 \pm 0.08$ & $0.14 \pm 0.08$ & $0.10 \pm 0.07$ & $0.11 \pm 0.05$ & $\overline{0.0 \pm 0.0}$ & $0.11 \pm 0.03$ \\
\hline \multirow[t]{3}{*}{ June } & $\mathrm{AM}$ & $0.25^{*} \pm 0.13$ & $0.0 \pm 0.0$ & $0.11 \pm 0.11$ & $0.12 \pm 0.08$ & $0.08 \pm 0.08$ & $0.11 \pm 0.04$ \\
\hline & PM & $\underline{0.0 \pm 0.0}$ & $\underline{0.62 * \pm 0.19}$ & $\underline{0.11 \pm 0.11}$ & $\underline{0.0 \pm 0.0}$ & $\underline{0.0 \pm 0.0}$ & $\underline{0.15 \pm 0.05}$ \\
\hline & TMean & $0 . \overline{13 \pm 0.07}$ & $0.31 \pm 0.11$ & $\overline{0.11 \pm 0.08}$ & $0.06 \pm 0.04$ & $0.04 \pm 0.04$ & $0.13 \pm 0.03$ \\
\hline \multirow[t]{3}{*}{ Aug. } & AM & $0.09 \pm 0.09$ & $0.0 \pm 0.0$ & $0.12 \pm 0.12$ & $0.26^{*} \pm 0.11$ & $0.0 \pm 0.0$ & $0.09 \pm 0.04$ \\
\hline & PM & $\underline{0.18 \pm 0.12}$ & $\underline{0.90^{*} \pm 0.34}$ & $\underline{0.0 \pm 0.0}$ & $\underline{0.0 \pm 0.0}$ & $\underline{0.0 \pm 0.0}$ & $\underline{0.22 \pm 0.08}$ \\
\hline & TMean & $0 . \overline{14 b \pm 0.08}$ & $\overline{0.45 a \pm 0.19}$ & $0 . \overline{06 \mathrm{~b} \pm 0.06}$ & $0.13 b \pm 0.06$ & $0.0 \mathrm{~b} \pm 0.0$ & $0.16 \pm 0.05$ \\
\hline \multirow[t]{3}{*}{ Oct. } & AM & $0.15 \pm 0.10$ & $0.0 \pm 0.0$ & $0.0 \pm 0.0$ & $0.25^{*} \pm 0.09$ & $0.0 \pm 0.0$ & $0.08 \pm 0.03$ \\
\hline & PM & $\underline{0.0 \pm 0.0}$ & $\underline{0.62 * \pm 0.17}$ & $\underline{0.19 \pm 0.13}$ & $\underline{00.0 \pm 0.0}$ & $\underline{0.0 \pm 0.0}$ & $\underline{0.16 \pm 0.05}$ \\
\hline & TMean & $0.07 b \pm 0.05$ & $0.31 \mathrm{a} \pm 0.10$ & $0.10 b \pm 0.07$ & $0.13 b \pm 0.05$ & $0 . \overline{0 b \pm 0.0}$ & $0.12 \pm 0.03$ \\
\hline
\end{tabular}

${ }^{1} \mathrm{AF}=$ alkali flats; $\mathrm{FG}=$ floodplain grassland; $\mathrm{SS}=$ shrub savanna; $\mathrm{TS}=$ tree savanna; $\mathrm{WL}=$ woodland.

${ }^{2} \mathrm{AM}=1^{\text {st }} 3$ hours after daylight; $\mathrm{PM}=1^{\text {st }} 3$ hours before dark.

${ }^{3} \mathrm{HTMean}=$ Mean for all habitat types per time or month.

${ }_{5}^{4}$ Year = Mean for all months per time and per habitat type.

${ }^{5}$ TMean $=$ Mean for both AM and PM per habitat type or month. 
growth during the early and mid wet season of PY94 with an early onset of the dry season. In PY95, early and mid season growth in PY95 was less than average, but the above average late wet season rains delayed the onset of the dry season.

\section{Relative Frequency of Observation of Herds}

A total of 909 herds of animals (kudu, 285; impala, 209; elephant, 200; giraffe, 138; and buffalo, 77) were observed over the 760 observation periods for an average of 1.20 herds per observation period and one herd of some species for every 15.5 $\mathrm{km}$ of route traveled. The average, adjusted (i.e., for different size habitat types) number of herds per observation period per habitat type for all animals combined was as follows: alkali flats (3.42), floodplain grassland (2.67), shrub savanna (2.29), tree savanna (1.04), and woodland (0.30).

The total number of observations for all herds was similar in PY94 (473) in PY95 (436) and for the wet (427) and dry seasons (482) seasons. However, there were large differences in the numbers of observations of herds due to kind of animal, month, habitat type, and time of day.

\section{Buffalo}

The average number of herds of buffalo for all observation periods was about 0.11 and varied only from 0.08 to 0.16 for the average of any month (Table 1). However, there were differences between habitat types and between times of day.

For the year, the greatest number of herds of buffalo were observed in the floodplain grassland and the lowest number in the woodland habitat type. This varied with time of day. During the morning, buffalo were observed most often in the tree savanna and alkali flats and least often in the floodplain grassland and woodland. Except for June, buffalo were never observed in the woodland. During the afternoon, buffalo were observed most often in the floodplain grassland. Buffalo sightings were much more numerous in the tree savanna in the morning than the afternoon and much more numerous in the floodplain grassland during afternoon than morning. These differences occurred, however, only in the late wet season (April) and all of the dry season (JuneOctober).
There was no significant difference in buffalo sightings in different habitat types during any month of the wet season (December-April) or the early part (June) of the dry season, but buffalo sightings were greater in the floodplain grassland in the mid (August) and late (October) dry season than in other habitat types.

\section{Elephant}

The overall average number of herds of elephant observed per observation period was 0.42 (Table 2). The numbers of herds sighted were similar during the wet season, then tended to increase and peak at the end of the dry season. The annual average elephant sightings per habitat type were in descending order as follows: floodplain grassland $(0.80)>$ alkali flats $(0.53) \geq$ shrub savanna $(0.41) \geq$ tree savanna $(0.27)>$ woodland $(0.11)$. In the morning, elephant sightings were about equal and more numerous in the alkali flats, shrub, and tree savannas than in the floodplain grassland or woodland, but in the afternoon elephant sightings were much greater in the floodplain grassland

Table 2. Numbers (mean \pm SE) of elephant herds observed per time period during different months, times of day, and in different habitat types in Chobe National Park, Botswana. ( $\mathrm{N}=6 / \mathrm{month} / \mathrm{time} / \mathrm{habitat}$ type). Means for habitat types for the same time or month followed by a different letter are statistically different at the $5 \%$ level of probability. Significant $(\mathrm{P}<0.05)$ differences between means for different times within habitat type and month are indicated by '**'.

\begin{tabular}{|c|c|c|c|c|c|c|c|}
\hline \multirow[b]{2}{*}{ Month } & \multirow[b]{2}{*}{ Time $^{2}$} & \multicolumn{5}{|c|}{ Habitat Type $^{1}$} & \multirow[b]{2}{*}{ HTMean $^{3}$} \\
\hline & & $\mathrm{AF}$ & FG & SS & TS & WL & \\
\hline \multirow[t]{2}{*}{ Year $^{4}$} & $\mathrm{AM}$ & $0.61 \mathrm{a} \pm 0.09$ & $0.16 b \pm 0.07$ & $0.56 a \pm 0.10$ & $0.45 * a \pm 06$ & $0.19 * b \pm 04$ & $0.39 \pm 04$ \\
\hline & PM & $0.45 b \pm 0.08$ & $1.44 * a \pm 0.18$ & $0.25 b c \pm 0.07$ & $\underline{0.09 c \quad \pm 03}$ & $\underline{0.03 c \pm 02}$ & $\underline{0.45 \pm 05}$ \\
\hline \multirow[t]{2}{*}{ Dec. } & $\mathrm{AM}$ & $1.10 \pm 0.26$ & $0.0 \pm 0.0$ & $0.68 \pm 0.26$ & $0.35 \pm 0.18$ & $0.16 \pm 0.11$ & $0.46 \pm 10$ \\
\hline & PM & $\underline{0.76 \pm 0.25}$ & $\underline{0.21 \pm 0.21}$ & $\underline{0.45 \pm 0.25}$ & $\underline{0.23 \pm 0.13}$ & $\underline{0.08 \pm 0.08}$ & $\underline{0.35 \pm 09}$ \\
\hline \multirow{2}{*}{ Feb. } & PM & $\underline{0.58 \pm 0.21}$ & $\underline{0.10 \pm 0.10}$ & $\underline{0.73 \pm 0.25}$ & $\underline{0.05 \pm 0.05}$ & $\underline{0.0 \pm 0.0}$ & $\underline{0.30 \pm 08}$ \\
\hline & TMean & $0 . \overline{49 a b \pm 0.14}$ & $0.05 \mathrm{~d} \pm 0.05$ & $0.78 \mathrm{a} \pm 0.19$ & $0 . \overline{42 b c \pm 0.11}$ & $0.1 \overline{1 c d \pm 0.06}$ & $\overline{0.37 \pm 06}$ \\
\hline \multirow[t]{3}{*}{ Apr. } & $\mathrm{AM}$ & $0.31 \pm 0.18$ & $0.0 \pm 0.0$ & $0.52 \pm 0.29$ & $0.49^{*} \pm 0.17$ & $0.07 \pm 0.07$ & $0.28 \pm 08$ \\
\hline & PM & $\underline{0.55 \pm 0.19}$ & $1.70 * \pm 0.41$ & $\underline{0.10 \pm 0.10}$ & $\underline{0.11 \pm 0.07}$ & $\underline{0.07 \pm 0.07}$ & $\underline{0.51 \pm 12}$ \\
\hline & TMean & $0.43 \mathrm{ab} \pm 0.13$ & $0.85 \mathrm{a} \pm 0.26$ & $0.31 b \pm 0.16$ & $0.30 \mathrm{~b} \pm 0.10$ & $0.07 \mathrm{~b} \pm 0.05$ & $0.39 \pm 07$ \\
\hline \multirow[t]{3}{*}{ Aug. } & $\mathrm{AM}$ & $0.46 \pm 0.25$ & $0.11 \pm 0.11$ & $0.49 \pm 0.21$ & $0.51 * \pm 0.17$ & $0.34 * \pm 0.10$ & $0.38 \pm 0.08$ \\
\hline & PM & $\underline{0.28 \pm 0.20}$ & $2.35^{*} \pm 0.42$ & $\underline{0.12 \pm 0.12}$ & $\underline{0.06 \pm 0.06}$ & $\underline{0.0 \pm 0.0}$ & $\underline{0.56 \pm 0.15}$ \\
\hline & TMean & $0.37 \mathrm{~b} \pm 0.16$ & $1.23 a \pm 0.32$ & $0.31 \mathrm{~b} \pm 0.12$ & $0.29 b \pm 0.10$ & $0.17 \mathrm{~b} \pm 0.08$ & $0.47 \pm 0.09$ \\
\hline \multirow[t]{3}{*}{ Oct. } & $\mathrm{AM}$ & $1.01 * \pm 0.24$ & $0.79 \pm 0.33$ & $0.58 \pm 0.27$ & $0.20 \pm 0.12$ & $0.07 \pm 0.07$ & $0.53 \pm 11$ \\
\hline & PM & $\underline{0.07 \pm 0.07}$ & $2.55^{*} \pm 0.51$ & $\underline{0.10 \pm 0.10}$ & $\underline{0.05 \pm 0.05}$ & $\underline{0.0 \pm 0.0}$ & $\underline{0.55 \pm 16}$ \\
\hline & TMean & $0.54 \mathrm{~b} \pm 0.15$ & $\overline{1.67 a \pm 0.34}$ & $0 . \overline{34 b \pm 0.15}$ & $0.13 b \pm 0.06$ & $0.03 b \pm 0.03$ & $\overline{0.54 \pm 10}$ \\
\hline
\end{tabular}

$\mathrm{AF}=$ alkali flats; $\mathrm{FG}=$ floodplain grassland; $\mathrm{SS}=$ shrub savanna; $\mathrm{TS}=$ tree savanna; $\mathrm{WL}=$ woodland.

${ }^{2} \mathrm{AM}=1^{\text {st }} 3$ hours after daylight; $\mathrm{PM}=1^{\text {st }} 3$ hours before dark.

${ }^{3} \mathrm{HTMean}=$ Mean for all habitat types per time or month.

${ }_{5}^{4}$ Year = Mean for all months per time and per habitat type.

${ }^{5}$ TMean $=$ Mean for both AM and PM per habitat type or month 
Table 3. Numbers (mean \pm SE) of giraffe herds observed per time period during different months, times of day, and in different habitat types in Chobe National Park, Botswana. ( $=6 / \mathrm{month} /$ time period/habitat type). Means for habitat types for the same time or month followed by a different letter are statistically different at the $5 \%$ level of probability. Significant $(P<0.05)$ differences between means for different times within habitat type and
month are indicated by '*

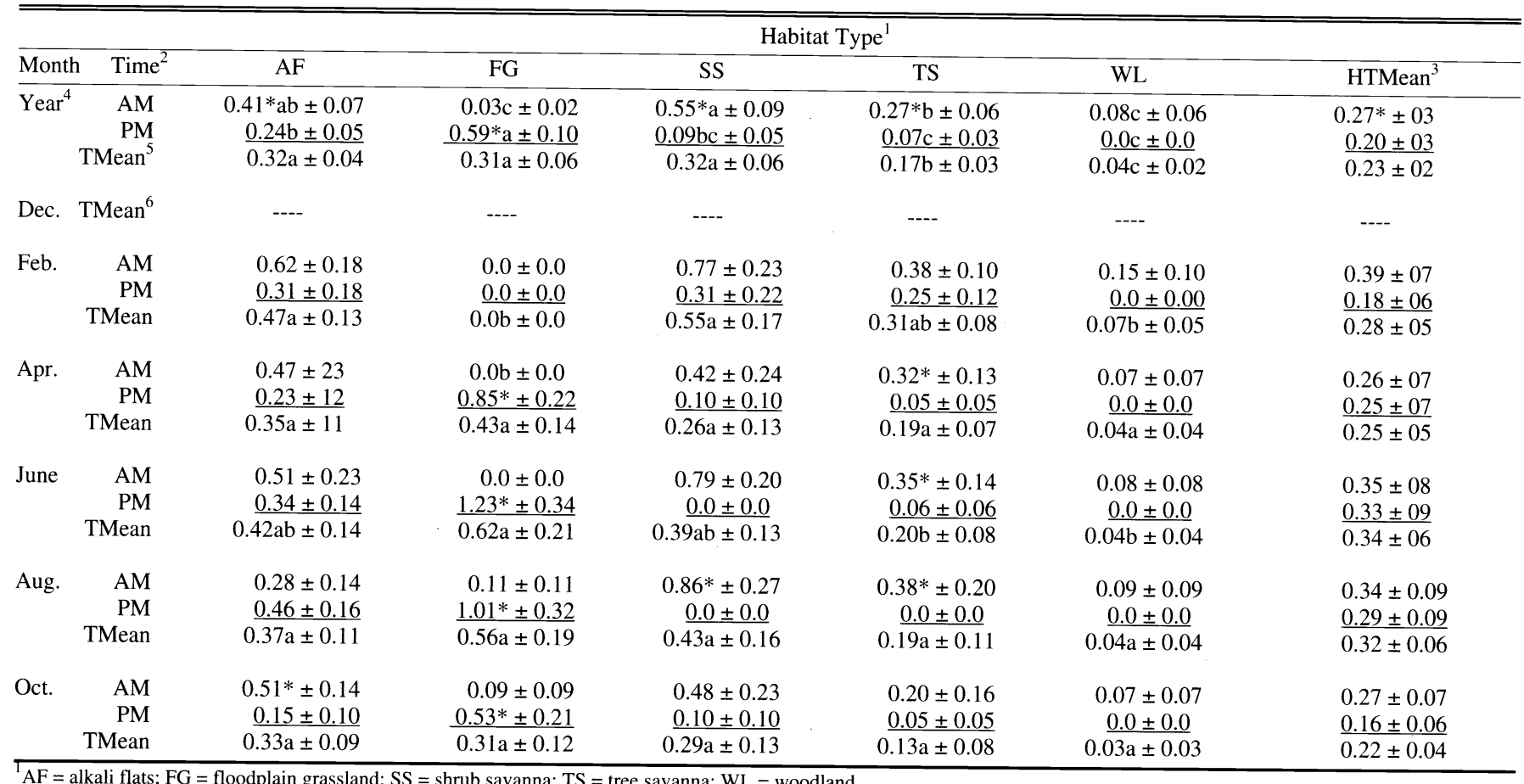

$\mathrm{AF}=$ alkali flats; $\mathrm{FG}=$ floodplain grassland $; \mathrm{SS}=$ shrub savanna; $\mathrm{TS}=$ tree savanna; $\mathrm{WL}=$ woodland

${ }_{3}^{2} \mathrm{AM}=1^{\text {st }} 3$ hours after daylight; $\mathrm{PM}=1^{\text {st }} 3$ hours before dark.

${ }^{3}$ HTMean $=$ Mean for all habitat types per time or month.

${ }^{4}$ Year = Mean for all months per time and per habitat type.

${ }^{5}$ TMean = Mean for both AM and PM per habitat type or month

${ }^{6}$ No giraffe were seen anywhere in the study area in December.

than anywhere else. Differences due to time of day were greatest for the tree savanna and woodland (i.e., the 2 habitat types farthest from the Chobe River) and the floodplain grassland (i.e., closest to the river).

Elephant sightings were relatively low in the floodplain grassland during the early and mid wet season, but were greater in the floodplain grassland than in any other habitat type thereafter. By the end of the dry season in October, elephant sightings in the floodplain grassland were 3 times greater than the overall habitat type average. However, elephants were never sighted in the floodplain grassland in the morning until the middle of the dry season. Conversely, elephant sightings were greater in the morning than in the afternoon in the tree savanna and woodland until late in the dry season. At this time, elephants tended to concentrate in the alkali flats in the morning and move out onto the floodplain grasslands in the afternoon.

\section{Giraffe}

The average number of giraffe sightings for all months, habitat types, and times of day was 0.23 (Table 3 ). This number was relatively similar for all months except
December, when giraffe were never seen anywhere in the study area.

On an annual basis, giraffe were most often seen and seen equally in the alkali flats, floodplain grassland, and shrub savanna, less often in the tree savanna, and least often in the woodland. However, as with the elephants, giraffe sightings were higher in the morning in the alkali flats and shrub savanna than elsewhere and higher in the afternoon in the floodplain grassland than elsewhere. Giraffe were never seen in the woodland in the afternoon.

The major difference in habitat preference occurred in February (mid wet season) and in June (beginning of the dry season). Giraffe preference for the floodplain grassland tended to increase from February to June and then decrease through October with the greatest difference in the afternoon.

\section{Impala}

The overall average number of impala sightings was 0.53 per observation period (Table 4). Unlike the sightings for other animals, impala sightings were significantly lower in April at the end of the wet season than during other months. Otherwise, the number of impala sightings during different months was very similar.

Impala preference for the alkali flats was about twice that for any other habitat type, although they were seen most often in the afternoon on the floodplain grassland. Impala were also seen about twice as often in the shrub savanna in the morning as in the afternoon and more often in the alkali flats in the morning than in the afternoon. Impala were never seen in the floodplain grasslands in the morning during any month, nor were impala ever seen in the woodland at either time of day or during any month of the year. The preference of impala for the alkali flats in the morning and the floodplain grassland in the afternoon became more pronounced as the seasons changed from wet to dry.

Impala preference for the alkali flats was much higher in the early-mid wet season and dry season than in the late wet season (i.e., April), and this low number of sightings in April on the alkali flats was the primary reason for the low monthly average in April for all habitat types. Impala preference for the floodplain grassland increased from low in the early-mid wet season to high in the mid-late dry season. 
Table 4. Numbers (mean \pm SE) of impala herds observed per time period during different months, times of day, and in different habitat types in Chobe National Park, Botswana. ( $N=6 /$ month/time/habitat type). Means for habitat types for the same time or month followed by a different letter are statistically different at the $5 \%$ level of probability. Significant $(P<0.05)$ differences between means for different times within habitat type and month are indicated by '*'.

\begin{tabular}{|c|c|c|c|c|c|c|c|}
\hline \multirow[b]{2}{*}{ Month } & \multirow[b]{2}{*}{ Time $^{2}$} & \multicolumn{5}{|c|}{ Habitat Type ${ }^{\prime}$} & \multirow[b]{2}{*}{ HTMean $^{3}$} \\
\hline & & $\mathrm{AF}$ & FG & SS & TS & WL & \\
\hline \multirow[t]{3}{*}{ Year $^{4}$} & $\mathrm{AM}$ & $1.45^{*} \mathrm{a} \pm 0.10$ & $0.0 \mathrm{c} \pm 0.0$ & $0.80 * b \pm 0.12$ & $0.14 c \pm 03$ & 5 & $0.48 \pm 04$ \\
\hline & PM & $\underline{1.09 a \pm 0.13}$ & $\underline{1.35 * \mathrm{a} \pm 0.17}$ & $\underline{0.34 b \pm 0.10}$ & $\underline{0.05 c \pm 02}$ & $\underline{----}$ & $\underline{0.57 \pm 06}$ \\
\hline & TMean $^{6}$ & $1.27 \mathrm{a} \pm 0.08$ & $0.67 b \pm 0.10$ & $0.57 b \pm 0.08$ & $0.09 \mathrm{c} \pm 02$ & $\overline{---}$ & $0.53 \pm 04$ \\
\hline \multirow[t]{3}{*}{ Dec. } & AM & $1.78 \pm 0.18$ & $0.0 \pm 0.0$ & $1.13 \pm 0.37$ & $0.0 \pm 0.0$ & ---- & $0.58 \pm 12$ \\
\hline & PM & $1.86 \pm 0.37$ & $\underline{0.21 \pm 0.21}$ & $\underline{0.68 \pm 0.31}$ & $\underline{0.06 \pm 0.06}$ & $\underline{----}$ & $\underline{0.56 \pm 14}$ \\
\hline & TMean & $1.82 a \pm 0.20$ & $0.10 \mathrm{c} \pm 0.10$ & $0.90 \mathrm{~b} \pm 0.24$ & $0.03 \mathrm{c} \pm 0.03$ & $\overline{----}$ & $0.57 \mathrm{a} \pm 09$ \\
\hline \multirow[t]{3}{*}{ Feb. } & $\mathrm{AM}$ & $1.67 \pm 0.20$ & $0.0 \pm 0.0$ & $1.06^{*} \pm 0.16$ & $0.16 \pm 0.09$ & ---- & $0.60 \pm 0.12$ \\
\hline & PM & $\underline{1.81 \pm 0.36}$ & $\underline{0.19 \pm 0.19}$ & $\underline{0.31 \pm 0.16}$ & $\underline{0.11 \pm 0.07}$ & $\underline{---}$ & $\underline{0.50 \pm 0.12}$ \\
\hline & TMean & $1.74 \mathrm{a} \pm 0.20$ & $0.10 \mathrm{c} \pm 0.10$ & $0 . \overline{70 b \pm 0.20}$ & $0.14 \mathrm{c} \pm 0.06$ & ---- & $0.55 \mathrm{a} \pm 0.08$ \\
\hline \multirow[t]{3}{*}{ Apr. } & $\mathrm{AM}$ & $0.70 \pm 0.21$ & $0.0 \pm 0.0$ & $0.42 \pm 0.28$ & $0.22 \pm 0.09$ & --- & $0.27 \pm 08$ \\
\hline & PM & $\underline{0.62 \pm 0.22}$ & $1.04 * \pm 0.37$ & $\underline{0.42 \pm 0.32}$ & $\underline{0.05 \pm 0.05}$ & $\underline{---}$ & $\underline{0.43 \pm 11}$ \\
\hline & TMean & $0.66 \mathrm{a} \pm 0.13$ & $0.52 \mathrm{ab} \pm 0.21$ & $0.42 \overline{a b c} \pm 0.21$ & $0.14 \mathrm{bc} \pm 0.06$ & --- & $0.35 b \pm 07$ \\
\hline \multirow[t]{3}{*}{ June } & $\mathrm{AM}$ & $1.52 \pm 0.27$ & $0.0 \pm 0.0$ & $0.90 * \pm 0.25$ & $0.29 * \pm 0.10$ & ---- & $0.54 \pm 11$ \\
\hline & PM & $1.35 \pm 0.23$ & $1.33^{*} \pm 0.39$ & $\underline{0.23 \pm 0.23}$ & $\underline{0.06 \pm 0.06}$ & $\underline{----}$ & $0.59 \pm 13$ \\
\hline & TMean & $1.44 \mathrm{a} \pm 0.10$ & $0.67 b \pm 0.23$ & $0.56 b c \pm 0.18$ & $0.18 \mathrm{~cd} \pm 0.06$ & ---- & $0.57 \mathrm{a} \pm 08$ \\
\hline \multirow[t]{3}{*}{ Aug. } & AM & $1.48^{*} \pm 0.29$ & $0.0 \pm 0.0$ & $0.98^{*} \pm 0.32$ & $0.13 \pm 0.09$ & ---- & $0.52 \pm 12$ \\
\hline & PM & $\underline{0.65 \pm 0.25}$ & $3.02 * \pm 0.19$ & $\underline{0.0 \pm 0.0}$ & $\underline{0.0 \pm 0.0}$ & $\cdots$ & $\underline{0.73 \pm 17}$ \\
\hline & TMean & $1.06 \mathrm{a} \pm 0.21$ & $1.51 \mathrm{a} \pm 0.34$ & $0 . \overline{49 b \pm 0.19}$ & $0.06 \mathrm{~b} \pm 0.04$ & ---- & $0.63 \mathrm{a} \pm 10$ \\
\hline \multirow[t]{3}{*}{ Oct. } & $\mathrm{AM}$ & $1.59 * \pm 0.28$ & $0.0 \pm 0.0$ & $0.39 \pm 22$ & $0.05 \pm 0.05$ & ---- & $0.41 \pm 10$ \\
\hline & $\mathrm{PM}$ & $\underline{0.29 \pm 0.17}$ & $2.37 * \pm 0.40$ & $\underline{0.39 \pm 22}$ & $\underline{0.0 \pm 0.0}$ & $\underline{----}$ & $\underline{0.61 \pm 14}$ \\
\hline & TMean & $0.94 \mathrm{a} \pm 0.20$ & $1.19 a \pm 0.30$ & $0 . \overline{39 b \pm 15}$ & $0.03 \mathrm{~b} \pm 0.03$ & ---- & $0.51 \mathrm{ab} \pm 09$ \\
\hline
\end{tabular}

$\mathrm{AF}=$ alkali flats $; \mathrm{FG}=$ floodplain grassland $; \mathrm{SS}=$ shrub savanna; $\mathrm{TS}=$ tree savanna; $\mathrm{WL}=$ woodland.

${ }^{2} \mathrm{AM}=1^{\text {st }} 3$ hours after daylight; $\mathrm{PM}=1^{\mathrm{st}} 3$ hours before dark.

${ }^{3}$ HTMean $=$ Mean for all habitat types per time or month.

${ }^{4}$ Year $=$ Mean for all months per time and per habitat type.

${ }^{5}$ Impala were never observed in the Woodland habitat type at any time during the study.

${ }^{6}$ TMean $=$ Mean for both AM and PM per habitat type or month.

Conversely, impala preference for the shrub savanna tended to be higher in the early-mid wet season than later in the year.

\section{Kudu}

The overall average number of kudu sightings was 0.66 per observation period (Table 5), the highest number for all 5 animals observed. The average number of sightings per month was relatively consistent (i.e., 0.57-0.76). The number of sightings in the morning and afternoon were generally similar each month except for October when more herds of kudu for all habitat types were seen in the morning than in the afternoon.

There were relatively large differences in the average number of sightings of kudu per habitat type, ranging from a high of 1.17 per observation period on the alkali flats down to 0.14 in the woodland habitat type. The average number of sightings per month was relatively consistent on the alkali flats, tree savanna, and woodland, but varied more widely in the shrub savanna and most widely on the floodplain grasslands (0.00 in February during flooding - 1.10 during the late dry season). By mid-late dry season, the number of kudu sightings was very similar on the alkali flats, floodplain grasslands, and shrub savanna - all 3 habitat types next to the Chobe River.

An interaction between habitat type and time of day also influenced the number of sightings of kudu; more kudu herds were seen in the morning than in the afternoon in the shrub savanna and woodland whereas more kudu herds were seen in the afternoon than in the morning on the floodplain grasslands.

Differences in the average number of sightings due to time of day also varied with month of observation within habitat type. The number of kudu sightings on the alkali flats in the morning and afternoon was similar in February and June, slightly greater in the afternoon than in the morning in December and August, much greater in the afternoon in April (i.e., late wet season), and much greater in the morning in October (i.e., late dry season). On the floodplain grasslands, large differ- ences due to time of day in the number of sightings only occurred in April through August, and the number of sightings was always higher in the afternoon. The most consistent effect of time of day on the number of kudu sightings occurred in the tree savanna where kudu were observed more often in the morning during all months of observation except December.

\section{Discussion}

The sighting of relatively numerous herds during February on the alkali flats may have resulted from a prey behavior pattern. Peak growth of both herbaceous and woody vegetation in all habitat types meant that visibility (Montfort 1973) was generally poor during the middle of the wet season. This is particularly important to those species, such as impala and kudu, which easily fall prey to predators (Pienaar 1963, Kingdon 1982). Buffalo fleeing from lion attack (Mills et al. 1995) also usually regrouped on the alkali flats 
Table 5. Numbers (mean \pm SE) of kudu herds observed per time period during different months, times of day, and in different habitat types in Chobe National Park, Botswana. ( $=6 / \mathrm{month} /$ time/habitat type). Means for habitat types for the same time or month followed by a different letter are statistically different at the $5 \%$ level of probability. Significant $(P<0.05)$ differences between means for different times within habitat type and month are indicated by ' $*$ '.

\begin{tabular}{|c|c|c|c|c|c|c|c|}
\hline \multirow[b]{2}{*}{ Month } & \multicolumn{7}{|c|}{ Habitat Type ${ }^{1}$} \\
\hline & Time $^{2}$ & $\mathrm{AF}$ & FG & SS & TS & WL & HTMean $^{3}$ \\
\hline \multirow[t]{3}{*}{$\overline{\text { Year }^{4}}$} & AM & $1.13 \mathrm{a} 5 \pm 0.11$ & $0.28 c \pm 0.09$ & $1.15 a \pm 0.15$ & $0.65 * b \pm 0.08$ & $0.20 * c \pm 0.05$ & $0.68 \pm 0.05$ \\
\hline & PM & $1.20 \mathrm{a} \pm 0.12$ & $1.05 * a \pm 0.16$ & $\underline{0.64 b \pm 0.11}$ & $\underline{0.17 c \pm 0.04}$ & $\underline{0.08 \mathrm{c} \pm 0.03}$ & $0.63 \pm 0.05$ \\
\hline & TMean $^{5}$ & $1.17 \mathrm{a} \pm 0.08$ & $0.67 \mathrm{c} \pm 0.10$ & $0.89 b \pm 0.10$ & $0.41 \mathrm{~d} \pm 0.05$ & $0.14 \mathrm{e} \pm 0.03$ & $0.66 \pm 0.04$ \\
\hline \multirow[t]{3}{*}{ Dec. } & $\mathrm{AM}$ & $1.01 \mathrm{ab} \pm 0.31$ & $0.10 \mathrm{c} \pm 0.10$ & $1.46 \mathrm{a} \pm 0.42$ & $0.58 b c \pm 0.21$ & $0.16 c \pm 0.11$ & $0.66 \pm 13$ \\
\hline & PM & $1.69 \mathrm{a} \pm 0.29$ & $\underline{0.21 b \pm 0.21}$ & $\underline{0.68 b} \pm 0.26$ & $0.35 b \pm 0.16$ & $0.16 \mathrm{~b} \pm 0.11$ & $\underline{0.62 \pm 12}$ \\
\hline & TMean & $1.35 \mathrm{a} \pm 0.22$ & $0.15 b \pm 0.11$ & $1.07 \mathrm{a} \pm 0.26$ & $0.47 b \pm 0.13$ & $0.16 b \pm 0.07$ & $0.64 \pm 09$ \\
\hline \multirow[t]{3}{*}{ Feb. } & $\mathrm{AM}$ & $1.23 a \pm 0.19$ & $0.0 \mathrm{c} \pm 0.0$ & $1.14 \mathrm{a} \pm 0.34$ & $0.70 * a b \pm 0.15$ & $0.22 * b c \pm 0.12$ & $0.67 \pm 10$ \\
\hline & PM & $1.17 \mathrm{a} \pm 0.38$ & $\underline{0.0 \mathrm{c} \pm 0.0}$ & $\underline{0.77 a b \pm 0.23}$ & $\underline{0.27 b c \pm 0.13}$ & $0.15 b c \pm 0.10$ & $0.48 \pm 11$ \\
\hline & TMean & $1.20 \mathrm{a} \pm 0.20$ & $\overline{0.0 \mathrm{c} \pm 0.0}$ & $0.95 \mathrm{a} \pm 0.20$ & $0.49 b \pm 0.11$ & $0.18 b c \pm 0.07$ & $0.57 \pm 07$ \\
\hline \multirow[t]{3}{*}{ Apr. } & $\mathrm{AM}$ & $0.78 a \pm 0.20$ & $0.0 \mathrm{c} \pm 0.0$ & $0.62 a b \pm 0.25$ & $0.59 * a b \pm 0.18$ & $0.22 * b c \pm 0.12$ & $0.44 \pm 0.08$ \\
\hline & PM & $1.64 * a \pm 0.25$ & $1.70 * a \pm 0.36$ & $\underline{0.31 b \pm 0.16}$ & $0.05 b \pm 0.05$ & $0.0 \mathrm{~b} \pm 0.0$ & $0.74 \pm 0.13$ \\
\hline & TMean & $1.21 \mathrm{a} \pm 0 . .18$ & $0.85 a b \pm 0.24$ & $0.47 b c \pm 0.15$ & $0.32 c \pm 0.11$ & $0.11 \mathrm{c} \pm 0.06$ & $0.59 \pm 0.08$ \\
\hline \multirow[t]{3}{*}{ June } & $\mathrm{AM}$ & $1.01 \mathrm{a} \pm 0.25$ & $0.21 b \pm 0.14$ & $1.01 \mathrm{a} \pm 0.41$ & $0.64 * a b \pm 0.20$ & $0.16 b \pm 0.11$ & $0.61 \pm 0.12$ \\
\hline & PM & $1.10 \mathrm{ab} \pm 0.23$ & $1.44 * a \pm 0.40$ & $0.68 b c \pm 0.31$ & $0.12 \mathrm{c} \pm 0.08$ & $\underline{0.0 \mathrm{c} \pm 0.0}$ & $\underline{0.67 \pm 0.13}$ \\
\hline & TMean & $1.06 \mathrm{a} \pm 0.17$ & $\overline{0.82 \mathrm{ab} \pm 0.24}$ & $0.84 a b \pm 0.26$ & $00.38 b c \pm 0.12$ & $0.08 \mathrm{c} \pm 0.05$ & $0.64 \pm 0.09$ \\
\hline \multirow[t]{3}{*}{ Aug. } & $\mathrm{AM}$ & $0.74 b \pm 0.31$ & $0.22 b \pm 0.15$ & $1.60 * a \pm 0.44$ & $0.77 * b \pm 0.24$ & $0.34 * b \pm 0.14$ & $0.73 \pm 0.14$ \\
\hline & PM & $1.38 a \pm 0.37$ & $1.90 * a \pm 0.48$ & $0.49 b \pm 0.33$ & $0.13 b \pm 0.13$ & $0.0 \mathrm{~b} \pm 0.0$ & $0.78 \pm 0.17$ \\
\hline & TMean & $1.06 \mathrm{a} \pm 0.25$ & $1.06 \mathrm{a} \pm 0.31$ & $1.04 a \pm 0.29$ & $0.45 \mathrm{ab} \pm 0.15$ & $0.17 b \pm 0.08$ & $0.76 \pm 0.11$ \\
\hline \multirow[t]{3}{*}{ Oct. } & $\mathrm{AM}$ & $1.88 * a \pm 0.26$ & $1.06 a b \pm 0.36$ & $1.16 a b \pm 0.37$ & $0.60 * b c \pm 0.23$ & $0.14 c \pm 0.09$ & $0.97 * \pm 0.14$ \\
\hline & PM & $\underline{0.36 b c \pm 0.17}$ & $1.14 a \pm 0.40$ & $0.87 \mathrm{ab} \pm 0.34$ & $\underline{0.10 \mathrm{c} \pm 0.07}$ & $\underline{0.14 c \pm 0.09}$ & $0.52 \pm 0.12$ \\
\hline & TMean & $1.12 \mathrm{a} \pm 0.21$ & $1.10 \mathrm{a} \pm 0.26$ & $1.01 \mathrm{a} \pm 0.25$ & $0.35 b \pm 0.13$ & $0.14 b \pm 0.06$ & $0.74 \pm 0.09$ \\
\hline
\end{tabular}

$\mathrm{AF}=$ alkali flats; $\mathrm{FG}=$ floodplain grassland; $\mathrm{SS}=$ shrub savanna; $\mathrm{TS}=$ tree savanna; $\mathrm{WL}=$ woodland.

${ }^{2} \mathrm{AM}=1^{\text {st }} 3$ hours after daylight; $\mathrm{PM}=1^{\text {st }} 3$ hours before dark.

${ }^{3}$ HTMean $=$ Mean for all habitat types per time or month.

${ }_{5}^{4}$ Year $=$ Mean for all months per time and per habitat type.

${ }^{5}$ TMean $=$ Mean for both AM and PM per habitat type or month

because they had a better view of the surrounding cover.

The relatively high numbers of herds during October occurred when available forage mineral supply was low (Bell 1970, Western 1975, McNaughton 1990), and many herds frequented the alkali flats to utilize the mineral licks (Klaus et al. 1998) located in this habitat type. However, the availability of evergreen woody plants, especially Capparis tomentosa Lam., may have also attracted browsers, such as kudu.

The high frequency of sighting herbivores on the floodplains during the dry season marks the importance of the Chobe River as the major contributing source of water for all animals in the study area. Some species, such as kudu and giraffe, which obtain much of their water needs from green leaves (Innis 1958, OwenSmith 1979) during the wet season, frequent the floodplain grasslands during dry season. Other water-dependent species like buffalo (Kingdon 1982, Mugangu et al. 1995), elephant (Laws 1970), and impala (Estes 1991) also use the floodplains during the dry season. Also, ani- mals generally have smaller home ranges with regard to the water sources (Estes 1991, Leuthold 1978) during the dry season and are easier to locate. The few ephemeral pans in the alkali flats, tree savanna, and shrub savanna may meet the water needs of many animals during the rainy season causing them to disperse widely during this season (Jarman 1979, Leuthold 1978, Pellew 1984).

The woodland habitat type had the lowest frequency of observation although it had the most available herbage. Early sprouting of both herbaceous and woody plants from dry season fires were common (Omphile 1997). This habitat type, despite being the greatest distance from the Chobe River, is still within the home ranges of all the study herbivores except the impala (Kingdon 1982). Elephants can cover distances in excess of $40 \mathrm{~km}$ on their daily foraging bouts (Douglas-Hamilton 1972). However, if the animals obtain sufficient forage from other habitat types closer to the river, traveling to the woodland would be a waste of energy. Resident elephant herds remain close to permanent water sources in northern Botswana, but migra- tory herds travel up to $200 \mathrm{~km}$ to reach water in the dry season (Verlinden and Gavor 1998).

The low frequency of sighting of buffalo herds in all habitats may have resulted from simply fewer herds with larger numbers per herd (Omphile 1997) or from their feeding habit described by Kingdon (1982) as "economic feeding" which involves short feeding bouts and longer rests. Buffalo only graze for an average of 9 hours in the 24-hour period, 5 or 6 hours of which are at night. This pattern of feeding allows only 3 to 4 hours of day-time activity, rendering it difficult to sight the animals during day. Winterbach and Bothma (1998), however, noted that buffalo in the South African 'Sourveld' (a suboptimal habitat for buffalo) showed the same circadian rhythm as other ruminants in the area: a few long feeding periods, followed by a few long ruminating and resting periods. Regardless, nighttime grazing was favored during the warmer months, and all drinking occurred during the day.

While the Chobe study area provides a variety of habitat types, it appears the loca- 
tion of the habitat with regard to water is an important element affecting elephant distribution as more bands were frequently sighted on the floodplains and the adjacent alkali flats. Water availability and use of salt licks (Henshaw and Ayeni 1971, Klaus et al. 1998) may also contribute to the preference of these habitat types during the dry season. Elephants were seen picking and eating soil balls in both the floodplains and the alkali flats during the dry season. In addition to providing the major source of water most of the year, the floodplains also provide some green grass during the dry season. Given the low levels of nitrogen and phosphorus observed in elephant dung during the dry season (Omphile 1997), it is not surprising that elephants spent more time where the chance of maximizing nutrient intake was greater.

Despite the woodland being the least preferred by giraffe, the habitat was still within their $12 \mathrm{~km}$ radius home range (Pellew 1984). It was likely that availability of adequate good forage in the other habitats within closer proximity to the Chobe River discouraged frequent use of the distant habitats like the woodlands. The alkali flats provided an abundance of an evergreen woody species Capparis tomentosa Lam., the late dry season blossoming Securinega virosa Roxb., Combretum mossambicense Klotzsch, and the late senescenting Croton megalobostrys. Both the shrub savanna and tree savanna provide the widest choice of browse species in addition to being closer to the river than the woodlands. The floodplains provide water as well as salt licks and adjacent riverine woody species, most of which are green throughout the dry season.

Impala habitat preference in the Chobe National Park reflects certain aspects of this antelope's special requirements which often produce an irregular and clumped distribution. Impala are ecotone species preferring light woodland with sparse undergrowth and grassland of low to medium height (Estes 1991). Also important are soils with free drainage, firm footing, level ground and free water. The 3 most preferred habitat types in this study (alkali flats, floodplains grassland and the shrub savanna) each offer at least 1 of these requirements.

The alkali flats also offer a variety of short grasses and scattered evergreens which impala appear to relish during the dry season. The floodplain is a source of water as well as short to medium height grasses whose dominance appears to be facilitated (McNaughton 1976, Perrin and Brereton-Stiles 1999) by buffalo, and ele- phant during the dry season.

The use of the shrub savanna is probably facilitated by the complementary heavy use of this habitat type by elephants. Heavy use over time shortens the heights of most dominant browse species and reduces canopy cover. However, the reduction of woody plant species does not extend into the adjoining tree savanna which is too densely vegetated and the soil too sandy and loose to make good impala habitat. During the dry season, however, more herds of impala were recorded in the tree savanna when visibility was greater and forage supply elsewhere within impala home range had declined. Even then, impala appeared to concentrate on northern fringes of this habitat type adjacent to the alkali flats and the shrub savanna

Most kudu sightings on the alkali flats, including those seen on the riverine ecotone, were recorded during the dry season when the need for the richest (Fritz et al. 1996, Owen-Smith 1979), but not necessarily the most varied vegetation, was relatively high. While the tree and shrub savannas offer more species of woody plants than the alkali flats, the quality of these species in the dry season has declined. However, kudu herds were seen in both habitats quite frequently during the rainy season indicating wet season preference for these habitats. Kudu sighted on floodplain grassland were either salting or drinking from the river; almost none were seen feeding as browse was limited to areas outside this habitat. In Zambia, kudu rarely entered the Kafue River floodplain during any season (Sheppe and Osborne 1971).

\section{Management Implications}

The greater frequency of sighting herbivores on the floodplain grassland and adjacent alkali flats and shrub savanna as opposed to the more distant habitat types of the tree savanna and woodland implies a disproportionate use of the KasaneNgoma section of the Chobe National Park. Animal concentrations in this area tend to increase competition for limited forage among ungulates with similar diets (Omphile 1997). This disproportionate use can lead to underutilization of some habitat types at the expense of others, a condition that may be driving the public and some special interest groups to suggest that the riverfront area of the park is over-utilized and, therefore, unattractive to tourists.

Our data confirm that tour operators interested primarily in providing their guests with a view of the greatest numbers of animals in a limited period of time are currently justified in congregating on the floodplain grassland in the afternoons during the dry season. However, a more widespread distribution of water and animal herds during the dry season should provide for a lower frequency of tourists seeing other tourist vehicles and, perhaps, a higher quality of wildlife-viewing experience for the Park visitors. As in most public wildlife reserves, Chobe National Park management is faced with the decision of how best to optimize the biological needs of the animals and their habitat with the economic and recreational desires of Park users.

\section{Literature Cited}

Bell, R.H.V. 1970. The use of herb layer by grazing ungulates in the Serengeti. p.111-123. In: A. Watson (ed.). Animal populations in relation to their food resources. Blackwell, London.

Child, G. 1968. An ecological survey of northeastern Botswana. F.A.O. Report T.A. 2563. United Nations, Rome.

Child, G. and W. Von Richter. 1968. Observations on ecology and behavior of linchwe, puku, and waterbuck along the Chobe River, Botswana. Z. Sangetierk. 34:275-295.

Dekker, B., N. van Rooyen, and J.D. Bothma. 1996. Habitat partitioning by ungulates on a game ranch in the Mopani veld. S. Afr. J. Wildl. Res. 26 117-122.

Douglas-Hamilton, I. 1972. On the ecology and behaviour of the African elephant. The elephants of Lake Manyara. D. Phil. Thesis, Oxford Univ.

Estes, R.D. 1991. The behavior guide to African mammals. Univ. Calif. Press, Los Angeles, Calif..

Field, D. 1978. Basic ecology for range management in Botswana. Min. of Agr., Gaborone.

FGU. Undated. Chobe National Park - a description of the resource. (Botswana Dept. Nat. Parks and Wildl. Mimeo.)

Fritz, H., M. de Garine-Wichatitsky, and G. Letessier. 1996. Habitat use by sympatric wild and domestic herbivores in an African savanna woodland: The influence of cattle spatial behaviour. J. Appl. Ecol. 33 589-598.

Henshaw, J. and J. Ayeni. 1971. Some aspects of big game utilization of mineral licks in Yankari Game Reserve, Nigeria. E. Afr. Wildl. J. 9:73-82.

Henry, F.W.T. 1966. Enumeration report on the Chobe main forest. Min. of Agr., Gaborone.

Innis, A. 1958. The behavior of the giraffe (Giraffa camelopardalis) in the eastern Transvaal. Proc. Zool. Soc. Lond. 35:129-146.

Jarman M.V. 1979. Impala social behavior. Beihefte Z. Tierpsychol. 21:1-92.

Kingdon, J. 1982. East. African mammals: an atlas of evolution in Africa. Vol. 3 part C (Bovids). Academic Press, New York. 
Klaus, G., C. Klaus-Hugi, and B. Schmid. 1998. Geophagy by large mammals at natural licks in the rain forest of the Dzanga National Park, Central African Republic. J. Trop. Ecol. 14 829-839.

Laws, R.M. 1970. Elephants as agents of habitat and landscape change in East Africa. Oikos 21:1-15.

Leuthold, B.M. 1978. Day time activity pattern of gerenuk and giraffe in Tsavo National Park, Kenya. E. Afr. Wildl. J. 16:129-141.

McNaughton, S.J. 1976. Serengeti migratory wildebeest: facilitation of energy flow by grazing. Science 191:92-94.

McNaughton, S.J. 1990. Mineral nutrition and seasonal movements of African migratory ungulates. Nature 345:6113-6115.

McNeeley, J.A. 1988. Economics and biological diversity: developing and using economic incentives to conserve biological resources. Int. Union Conserv. Nature Nat. Resources, Gland, Switzerland.

Miller, O.B. 1939. The mukusi forests of Bechuanaland. Emp. For. J.18:193-201.

Mills, M.G.L., H.C. Biggs, and I.J. Whyte. 1995. The relationship between rainfall, lion predation and population trends in African herbivores. Wildl. Res. 22 75-87.
Montfort, A. 1973. Notes sur l'ecologie et le comportement des oribis (Qurebia qurebi, Zimmermann 1783). Terre el Vie. 28:169, 208.

Mugangu, T.E., M.L. Hunter, and J.R. Gilbert. 1995. Food, water, and predation: A study of habitat selection by buffalo in Virunga National Park, Zaire. Mammalia 59 349-362.

Omphile, U.J. 1997. Seasonal diets, diet quality and habitat preference of large, savanna ungulates in the Chobe National Park, Botswana. Ph.D. Dissertation, Univ. Wyo. Laramie, Wyo.

Owen-Smith, N. 1979. Assessing the foraging efficiency of a large herbivore, the kudu. S Afr. J. Wildl. Res. 9:102-110.

Pienaar, U. de V. 1963. Large mammals of the Krueger National Park - their distribution and present day status. Koedoe 6:1-37.

Pellew, R.A. 1984. The feeding ecology of a selective browser, the giraffe (Giraffa camelopardalis). J. Zool. Lond. 202:57-81.

Perrin, M.R. and R. Brereton-Stiles. 1999. Habitat use and feeding behaviour of the buffalo and the white rhinoceros in the Hluhluwe-Umfolozi Game Reserve. S. Afr. J. Wildl. Res. 29:72-80.
SAS. 1985. SAS user's guide. Version 6 ed SAS Institute Inc. Raleigh, N. C..

Selous, F.C. 1881. A hunter's wanderings in Africa. London.

Sheppe, W. and T. Osborne. 1971. Patterns of use of a flood plain by Zambian mammals. Ecol. Monogr. 41:179-205.

Steel, R.G.D. and J.H. Torrie. 1980. Principles and procedures of statistics. $2^{\text {nd }}$ ed. McGrawHill Book Co., Inc. New York, N. Y.

Verlinden, A. and I.K.N. Gavor. 1998. Satellite tracking of elephants in northern Botswana. Afr. J. Ecol. 36 105-116.

Western, D. 1975. Water availability and its influence on the structure and dynamics of a savanna large mammal community. E. Afr. Wildl. J. 13:265-286.

Winterbach, H.E.K. and J.D. Bothma. 1998. Activity patterns of the Cape buffalo Syncerus caffer caffer in the Willem Pretorius Game Reserve, Free State. S. Afr. J. Wildl. Res. 28:73-81. 